\title{
Pulmonary cancer case with unique radiological findings
}

\section{İlginç radyolojik görünümü olan akciğer kanseri olgusu}

\author{
Mustafa Kuzucuoğlu \\ Balıkesir Üniversitesi Tıp Fakültesi, Göğüs Cerrahisi Ana Bilim Dalı, Balıkesir
}

Dergiye Ulaşma Tarihi: 20.02.2017 Dergiye Kabul Tarihi:28.03.2017 Doi: 10.5505/aot.2017.98698

\section{ÖZET}

Akciğer kanserlerinin tanısında radyolojik görüntüleme yöntemleri önemli yer tutmaktadır. İleri tetkiklerin planlanmasında bilgisayarlı tomografiler yol gösterici olmaktadır. Bu yazıda nefes darlığı ve öksürük yakınmaları olan 66 yaşında akciğer kanseri tanısı konan kadın olgunun atipik radyolojik bulguları sunuldu ve literatür eşliğinde akciğer kanserinin radyolojik bulguları değerlendirildi.

Anahtar Kelimeler: Akciğer kanseri, bilgisayarlı tomografi, tanı

\begin{abstract}
Radiological findings have important role in diagnosis of lung cancers. Computerized tomography works as a guide for planning further examinations. In this article, unique radiological findings of 66 years old female patient with shortness of breath and cough are presented; also radiological findings of lung cancer are explained with the help of literature.
\end{abstract}

Keywords: Lung cancer, computer tomography, diagnosis

\section{Giriş}

Akciğer kanserlerinin tanısal yaklaşımı genellikle radyolojik tetkikler ile başlar. Akciğer grafisi ve akciğerin bilgisayarlı tomografisi (BT) ile elde edilen bulgular tanı konusunda yönlendirici olmaktadır. Son y1llarda gelişmekte olan görüntüleme yöntemleri ile elde edilen radyolojik bulgular ile tanıya ulaşmak daha da kolaylaşmıştır.

$\mathrm{Bu}$ çalışmada net kitle bulgusu saptanamayan ilginç radyolojik görünümü nedeniyle bir akciğer kanseri hastası sunulmuştur.

\section{Olgu Sunumu}

Altmışaltı yaşında kadın hasta diz protezi ameliyatı hazırlığı için çekilen akciğer grafisinde bilateral yamasal infiltratif lezyonları olması üzerine gögüs hastalıkları polikliniğine yönlendirilmiş (Resim 1). Burada alınan öyküsünde uzun zamandır geçmeyen öksürügü ve nefes darlığı olduğunu söyleyen hastaya toraksın yüksek çözünürlüklü bilgisayarlı tomografisi (YÇBT) istenmiş. YÇBT'de her iki akciğerde rastgele dağılım gösteren nodüler lezyonlar saptanmış. Hastanın metastaz, enfeksiyon hastalıkları ve intertisyel akciğer hastalıkları yönünden araştırılması önerilmiş (Resim 2). Yapılan tetkiklerinde C-reaktif protein ve hafif lökositoz dişında patoloji saptanmamış. Hastaya bronkoskopi yapılmış. Endobronşial lezyon saptanmamış. Alınan lavaj örneklerinde patolojik tanı konulamamış. Primer odak arama amaçlı hastaya batın BT ve boyun ultrasonografisi istenmiş. Tiroid bezinde nodül saptanan hastaya tiroid ince iğne aspirasyon biyopsisi uygulanmış. Benign olarak raporlanmış. Hasta tanısal amaçlı biyopsi yapılması için gögüs cerrahisi polikliniğine yönlendirilmiş. Hastaya sağ lateral mini torakotomi uygulandi. Yapilan eksplorasyonda akciğerin sertleşmiş olduğu, alt ve üst lobda yer yer daha sert nodüler lezyon alanları olduğu görüldü. Üst ve alt lobun fissüre bakan yüzlerinden küçük wedge rezeksiyonlar uygulanarak doku biyopsisi alındı. Hastanın üst lobdan alınan biyopsi patolojisi 'Squamoz Hücreli Karsinom', alt lobdan alınan biyopsi ise 'Adenokarsinom' olarak raporland1. Hastaya evreleme amaçlı pozitron emisyon tomografisi (PET/BT) istendi. PET/BT'de her iki akciğerdeki nodüler lezyonlarda 
SUVmax:4,91-6,34 arasında değişen tutulum, mediastinal lenf nodlarinda SUVmax:3,3-6,9 arasında değişen tutulum saptandi. Tedavi amaçlı onkolojiye sevk edilen hasta tedavi başlanamadan solunum sikıntısı nedeniyle exitus oldu.

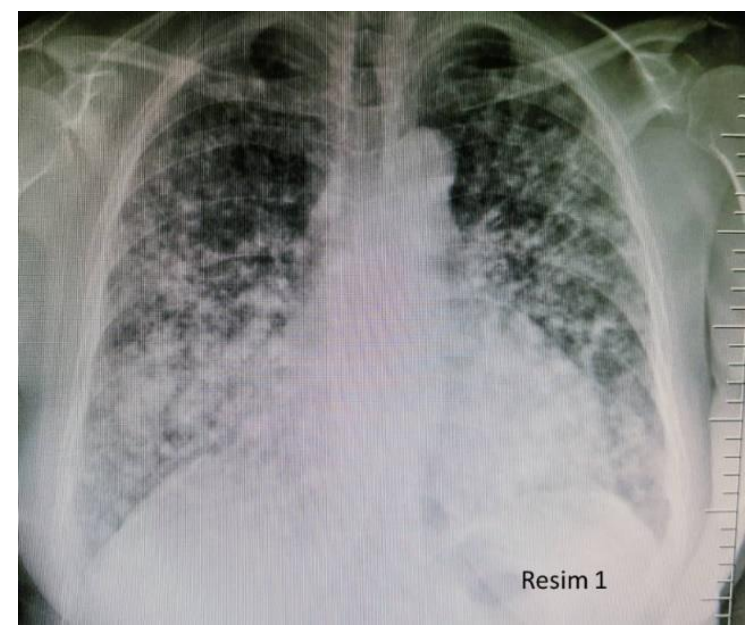

Resim 1: Olgunun geliş akciğer grafisi

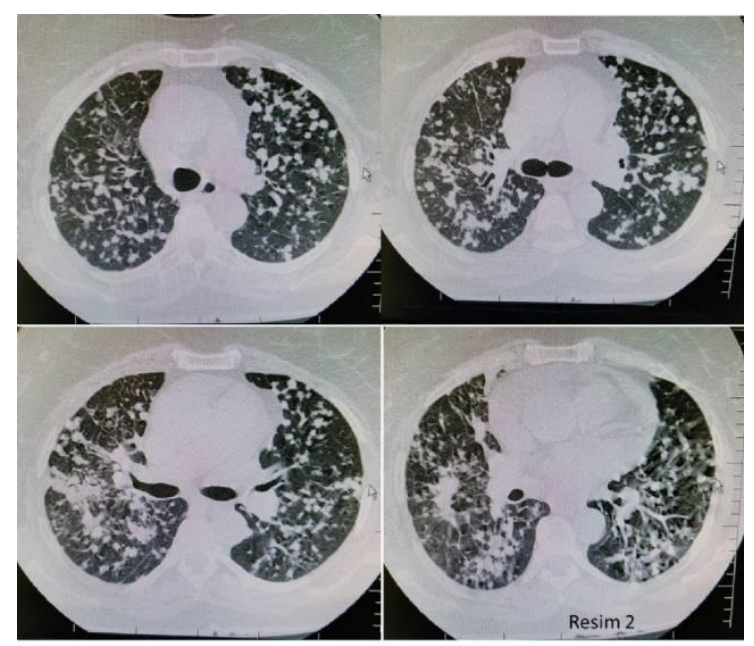

Resim 2: Olgunun geliş toraks bilgisayarlı tomografisi

\section{Tartışma}

Bilgisayarlı tomografi akciğer kanserinde temel görüntüleme yöntemidir. Klinik şüphe ya da akciğer grafisinde şüpheli görünüm olması durumunda mutlaka istenmelidir. Kabaca görüntüleme tetkiklerinde saptanan lezyonlar pulmoner nodül ya da kitle, buzlu cam opasiteleri, konsolidasyonlar şeklinde ortaya çıkar. Akciğer kanserinin yerleşim yeri ve histopatolojik alt tipine göre görüntüleme bulguları değişiklik gösterir $(1,2)$.
Periferik yerleşimli tümörler akciğer kanserlerinin yaklaşık \%42'sini oluştururken, bunların \%20-30'u periferik nodül şeklinde başlar (1). Nodül şeklinde ortaya çıkan akciğer tümörü; çap1 1-3 cm arasında değişen, genellikle düzgün sınırlı, oval şekilli, lobüle yapıda 'coin lezyon' olarak adlandirılan görünüme yol açarlar (3).

Segmenter ve subsegmenter bronşlardan köken alan tümörler bronşta tıkanmaya ve mukus birikimine yol açarak bronkosel oluşumuna neden olurlar. Hava bronkogramları ise alveolar dolum gösteren durumlarda gözlenir $(1,4)$.

Santral yerleşimli akciğer kanserleri endobronşial lezyonlar ve perihiler lezyonlar olarak ortaya çıkarlar. Genellikle hiler genişleme ve bronş tıkanmasına bağlı tümörün periferinde kollaps ve konsolidasyon şeklinde kendini gösterir. Kollaps olan alanda pnömoni tabloya eşlik eder. Santral tümörleri sıklıkla squamoz hücreli karsinomlar oluşturmaktadır $(1,4)$.

Histolojik alt tiplerine göre ise adenokarsinomlar akciğer kanserlerinin yaklaşık \%30'unu oluşturur ve radyolojik olarak ince kesit BT incelemelerinde k1smen solid yapı içeren buzlu cam opasiteleri ile karakterizedir (5). Squamoz hücreli karsinomlar ise radyolojik olarak genellikle kavitasyon gösteren santral kitleler ve bronşial tıkanmaya bağlı postobstruktif pnömoni şeklinde bulgu verirler. Sıklıkla küçük hücreli akciğer karsinomunun radyolojik bulgularında sinırları belirgin kitle lezyonu ile birlikte multiple patolojik mediastinal lenf nodlarıda saptanmaktadır (1). Bronkoalveolar karsinomlarda ise lezyon tek bir nodül şeklinde görülebileceği gibi lobun konsolidasyonu ya da multifokal yamasal konsolidasyon şeklinde de ortaya çıkabilir (6).

Squamoz hücreli karsinomlarda volüm kaybı olmaksızın konsolidasyon gelişmesi ender gelişen bir durumdur (7). Bizim olgumuzda da endobronşial lezyon olmaksızın ve periferal atelaktazi gelişmeksizin bilateral yaygın konsolidasyon alanları görülmekteydi. Hastaya atipik pnömoni ya da intertisyel akciğer hastalığı olabilir şüphesi ile antibiyotik ve steroid tedavileri uygulandi. Solunum sikintıs1 olan hastada belirgin rahatlama sağlanamadi. Malignite tanısının da ekarte edilememesi üzerine hastaya tanı açık akciğer biyopsisi ile konuldu. 
Finansal destek: Yazarlar finansal destek almadığını beyan etmiştir.

\section{Referanslar}

1. Akciğer kanserinde radyolojik bulgular. $B a l c ı P$, Altay C. Trd Sem 2014; 2:304-15.

2. Erol S, Şen E. Radyolojik olarak akciğer kanserinin ayırıcı tanısında düşünülmesi gereken enfeksiyon ve malignite dışı pulmoner hastalıklar. Toraks Cerrahisi Bülteni 2015; 9: 303-6.

3. Hollings N, Shaw P. Diagnostic imaging of lung cancer. Eur Respir J 2002; 19: 722-42.

4. Kuriyama K, Tateishi R, Doi O, Higashiyama M, Kodama K, Inoue E, et al. Prevalence of air bronchograms in small peripheral carcinomas of the lung on thin-section CT: comparison with benign tumors. AJR Am J Roentgenol 1991;156: 921.

5. Prokop CS. Conventional and CT diagnostics of bronchial carcinoma. Radiologe 2010; 50: 67583.

6. Köktürk N, Gürsel G, Köktürk O, Memiș L, Numan E. İlginç radyolojisi nedeniyle bir yassı hücreli akciğer kanseri olgusu. Akciğer Arşivi: 2005; 1: 37-39.

7. Meysman M, Schoors DF, Reynaert H, Nappen M, Pierre E, Vincken W. Respiratory Failure with Diffuse Patchy Lung Infiltrates: An Unusual Presentation of Squamous Cell Carcinoma. Thorax 1994; 49 (12): 1271-2. 